University of Nebraska - Lincoln

DigitalCommons@University of Nebraska - Lincoln

Faculty Publications from the Harold W. Manter Laboratory of Parasitology

1951

\title{
Hydatid Disease (Echinococcosis) in Alaska and the Importance of Rodent Intermediate Hosts
}

\author{
Robert L. Rausch \\ Arctic Health Research Center, rausch@u.washington.edu \\ Everett L. Schiller \\ Arctic Health Research Center
}

Follow this and additional works at: https://digitalcommons.unl.edu/parasitologyfacpubs

Part of the Parasitology Commons

Rausch, Robert L. and Schiller, Everett L., "Hydatid Disease (Echinococcosis) in Alaska and the Importance of Rodent Intermediate Hosts" (1951). Faculty Publications from the Harold W. Manter Laboratory of Parasitology. 481.

https://digitalcommons.unl.edu/parasitologyfacpubs/481

This Article is brought to you for free and open access by the Parasitology, Harold W. Manter Laboratory of at DigitalCommons@University of Nebraska - Lincoln. It has been accepted for inclusion in Faculty Publications from the Harold W. Manter Laboratory of Parasitology by an authorized administrator of DigitalCommons@University of Nebraska - Lincoln. 


\section{Hydatid Disease (Ecbinococcosis) in Alaska and the Importance of Rodent Intermediate} Hosts

\author{
Robert Rausch and Everett L. Schiller \\ Arctic Healtb Researcb Center, U. S. Public Healtb \\ Service, Ancborage, Alaska
}

Hydatid disease, caused by the larval form of a tapeworm, Echinococcus granulosus (Batsch, 1786), is of circumpolar distribution, but has not previously been considered to be of much public health significance in North America. It is the purpose of this paper to present observations on this disease in Alaska, with special reference to its transmission to man.

Magath (1) reviewed all known North American cases and concluded that most of these had been contracted abroad. Infections in dogs have likewise been considered rare; in his review of the literature, Riley (2) could find but one North American record and concluded that wild carnivora and herbivora serve to maintain this parasite in the United States and Canada. Subsequent work has borne out this conclusion. The occurrence of $E$. granulosus in wild animals in North America has been reviewed by McT. Cowan (4).

The data derived from intensive parasitological investigations of the mammalian fauna of Alaska, carried on by us over the past two years, indicate that E. granulosus is well established in the Territory, in both dogs and wild canids. In arctic Alaska, particularly, where dogs are commonly very closely associated with man, there is unusual opportunity for human exposure to this parasite. The finding of infected dogs in several arctic Eskimo villages (Barrow, Kotzebue, Wainwright, Unalakleet, Anaktuvuk Pass) indicates that potentially, if not actually, a serious human health problem is involved. In addition, we have recorded this parasite from both red and arctic foxes in northern Alaska, and from the wolf over the greater part of the Territory. Moose and caribou apparently serve as the essential intermediate hosts on the mainland, since the examination of several hundred mammals of other species has failed to disclose the larval infection. The practice of the natives of feeding dogs the discarded parts from moose and caribou enhances the possibilities for canine infection.

Although the status of hydatid disease in Alaska is in general poorly known, preliminary studies on St.

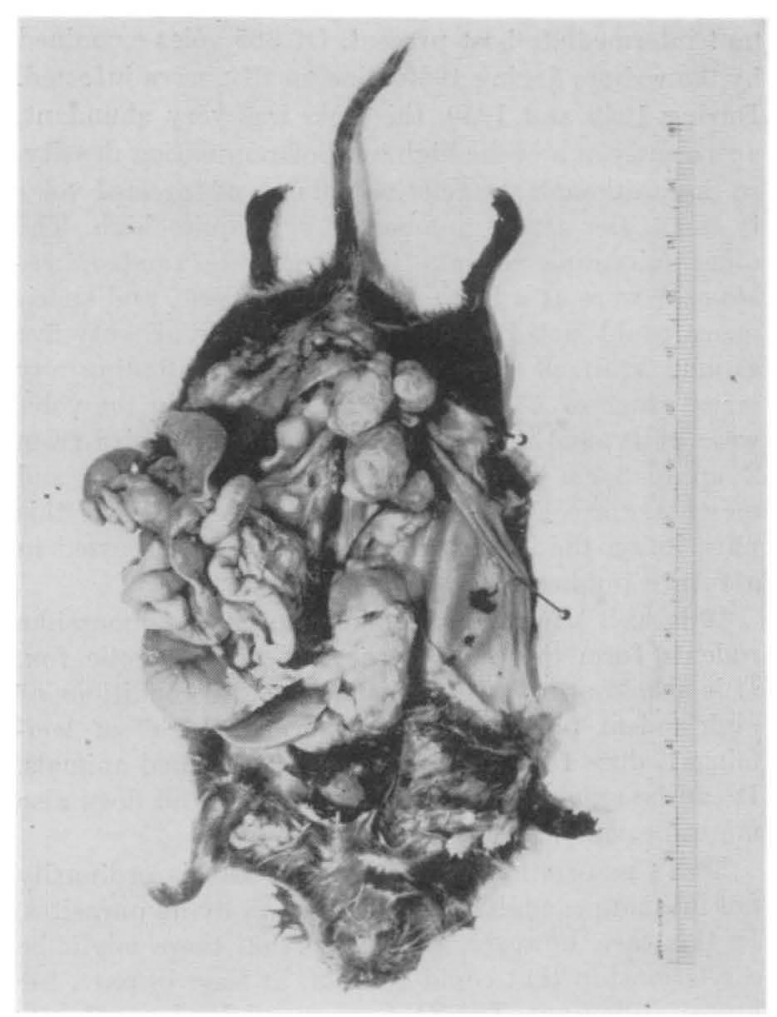

FIG. 1. Specimen of Microtus oeconomus showing location and appearance of larval cysts of $E$. granulosus.

Lawrence Island have disclosed, through skin tests with nonspecific Echinococcus antigen, a high incidence of human reactors. In the villages of Gambell and Savoonga, positive reactions of $20 \%$ (126 persons tested) and 28\% (106 persons tested), respectively, were obtained. As is usual under native conditions, dogs here are found in close association with man, but not to any greater degree than in arctic Alaska in general.

Autopsy of 26 St. Lawrence Island dogs failed to disclose any animals infected with $E$. granulosus. Five of 7 arctic foxes (Alopex lagopus), likewise examined, were found to be infected, however. The mammalian fauna of the island is poor as far as land species are concerned. Red foxes (Vulpes sp.) are rare, but occur in small numbers. Various rodents are present: tundra vole (Microtus), red-backed vole (Clethrionomys), lemming (Dicrostonyx), ground squirrel (Citellus). A shrew (Sorex) occurs on St. Lawrence Island, and the reindeer has been introduced. Of these, only the reindeer is an obvious intermediate host for $E$. granulosus. For some years, however, this animal has not been killed for food, since an effort is being made to increase its numbers. In view of this situation, some other explanation for fox infections was necessary.

Schiller, during the summer of 1950, discovered infections of larval $E$. granulosus in the tundra vole, Microtus oeconomus inuitus Merriam, and all available evidence indicates that this rodent is the only impor- 
tant intermediate host present. Of 385 voles examined by the writers during 1950, nine, or $2 \%$, were infected. During 1949 and 1950, this vole was very abundant, apparently at a cyclic high level of population density, so that, although the relative number of infected voles is small, the actual number may be quite high. The other microtine rodents (Clethrionomys and Dicrostony $x$ ) were at a low point in their cycle, and specimens could not be collected for study. Eighty-five ground squirrels were examined without finding any larval stage of $E$. granulosus. The larvae in the voles were of typical appearance, and ranged in size from 2 up to $3 \mathrm{~cm}$ in diameter (Fig. 1). The liver and mesentery are commonly involved. The effect of this parasite on the intermediate host will be discussed in a future publication.

It is well known that various species of mouselike rodents form the bulk of the diet of the arctic fox. It is also known that, particularly under conditions of high rodent populations (e.g., eyclic "high" of lemmings), dogs feed upon these easily obtained animals. It can be assumed that St. Lawrence Island dogs also might become infected from this source.

Man's association with the aretic fox is ordinarily not intimate enough to allow infection by its parasites. In this case, however, it appears that there might be a relationship that could account, at least in part, for human infections. The St. Lawrence Island people are hunters, depending almost entirely upon the flesh of sea mammals for their subsistence. During the summer months, however, a considerable quantity of a native green plant, as yet unidentified by us, is consumed. This plant is eaten in the field, unwashed and raw, as it comes from the ground. Aretic foxes are so abundant that it can be assumed that there is considerable contamination of the vegetation. It is of interest that Riley (3) stated that human cases of hydatid infection may be contracted by eating wild fruits contaminated by eggs from the feces of infected canids.

Not all factors involved in the epidemiology of the human infections are known. Some infections may result from ingesting eggs from the feces of dogs. Although they are perhaps not commonly infected now, it is possible that dogs harbored $E$. granulosus more often in former years when reindeer entered much more into the economy of the people. Reindeer serve as suitable intermediate hosts for this parasite in Alaska (4), and, when they were formerly slaughtered for food, waste parts were undoubtedly available to dogs. Organs such as lungs, in which the larval forms of $E$. granulosus often localize, are usually discarded, as would be anything of unusual appearance such as a large hydatid cyst. It is also possible that the water supply could afford opportunity for human infections, since water is obtained from sources open to fecal contamination by dogs and foxes.

Further investigation may disclose that hydatid disease in Alaska constitutes a serious public health hazard. On St. Lawrence Island, at least, in addition to the positive skin reactions, there is considerable clinical evidence of echinococcosis. Although a thorough elinical study of the reactors has not yet been made, there has been some opportunity for incidental observations. During the past two years two patients from the small population of St. Lawrence Island have undergone surgery for the removal of liver abcesses, and one man still has a post-operative draining sinus. Routine examination of various individuals by Alaska Department of Health personnel has indieated presence of an unusual number of nodular livers.

From the work so far, it is concluded that interstate shipment of dogs from arctic America should be prohibited. These investigations are being continued, and it is hoped that further work will disclose the over-all status of echinococeosis in Alaska, and lead to suitable control measures.

\section{References}

1. Magath, T. B. Penn. Med. J., 1 (April 1941).

2. MCT. COWAN, I. J. Wildlife Man., 12, 105 (1948).

3. RILEY, W. A. Minnesota. Med. 16, 744 (1933).

4. HADWEN, S., and Palmer, L. J. USDA Bull. 1089, 1 (1922). 